\title{
Full Circle or Spiralling Out of Control? State Violence and the Control of Urbanisation in Papua New Guinea
}

\author{
Gina Koczberski, George N. Curry and John Connell
}

[Paper first received, August 2000; in final form, March 2001]

Summary. There is an administrative reluctance to recognise the permanency of urban settlement in Papua New Guinea. This reluctance, evident since the 1960s, has been characteristic of both the colonial and post-colonial administrations. Opposition to some facets of urbanisation continues today, despite growing population and land pressures in most rural areas and real problems of landlessness emerging in particular rural areas. Colonial control of urban populations has been replicated in contemporary times, often in more draconian form. Eviction of urban settlers has been tied to issues of crime and urban respectability, and lingering perceptions that Melanesians should be rural residents. The growth of informal settlements and urbanisation are not seen as issues of urban planning, nor is the context of urban migration linked to socioeconomic inequality, hence other forms of urban policy are largely absent. Strengthening alliances between land-owners and the state (especially police and provincial administrations) have thus emphasised intraurban inequality and hampered national development.

\section{Introduction}

Urbanisation in Papua New Guinea is a relatively recent phenomenon. Until the early 1960s, towns and cities in Papua New Guinea were primarily European colonial administrative centres. Presently, Papua New Guinea's urban population accounts for 15 per cent of the national population, which is lower than in other Melanesian and Pacific Island nations (Ward, 1997). Despite the relatively limited extent of urbanisation, the rate of urban population growth since the 1960s has been, at times, extraordinarily high. Between 1966 and 1971, Papua New Guinea's urban population grew at over 16 per cent per annum (Jackson, 1977). Since
1980, the rate of urbanisation has slowed with growth concentrated in the three largest cities of Port Moresby, Lae and Madang (Connell, 1997) (Figure 1). Port Moresby's annual growth rate from 1980 to 1990 was 5.3 per cent (National Statistical Office, 1994) and that growth continued at around this rate throughout the 1990s. ${ }^{1}$

From the early colonial period, a pervasive anti-urbanism and an administrative reluctance to recognise the permanency of urban settlement have been at the heart of Papua New Guinea's national development policy and practice. Urbanisation was slow in colonial times and Michael Somare, just prior to 


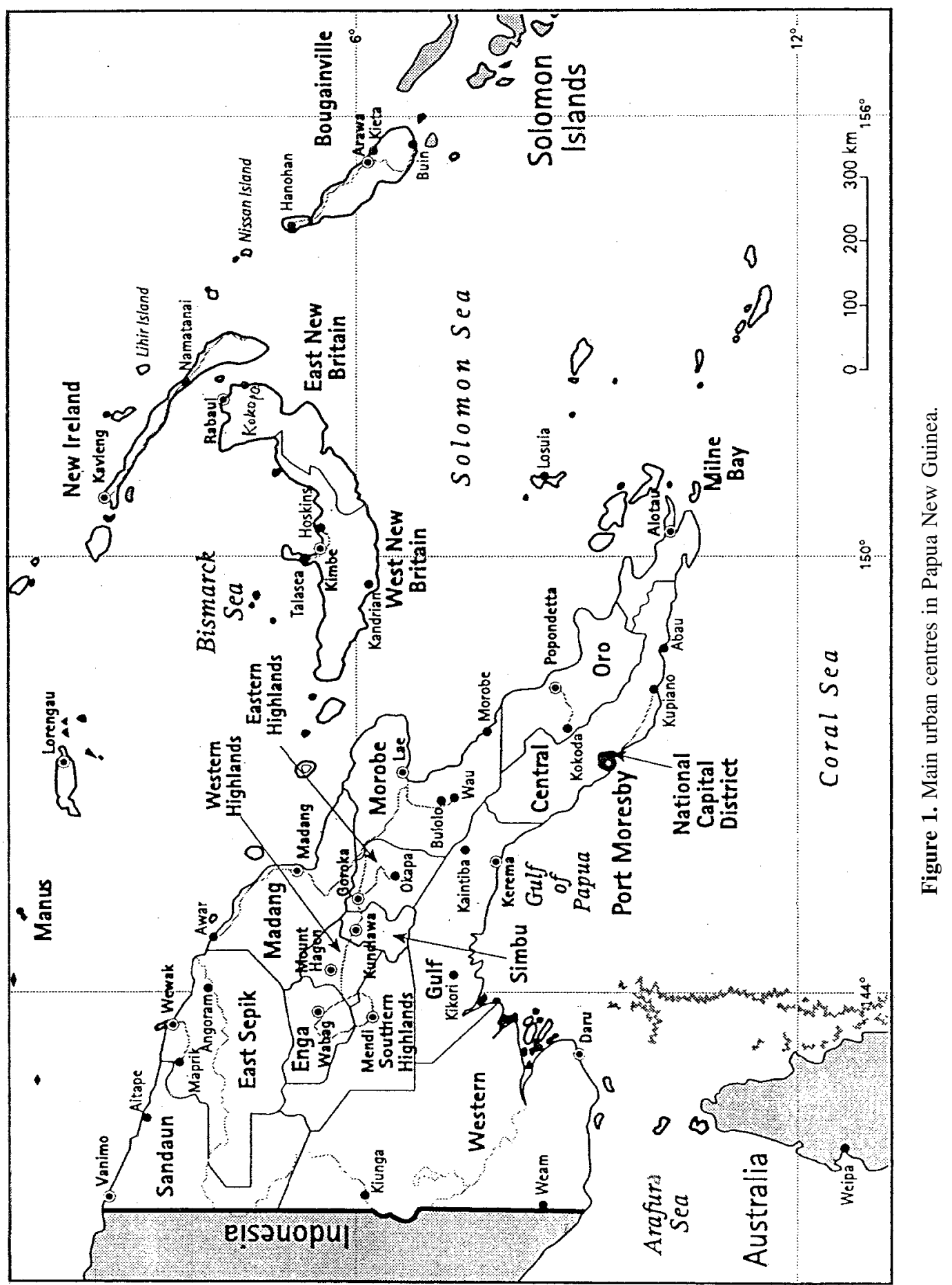


becoming the first Prime Minister of Papua New Guinea on its independence in 1975, posed the rhetorical question

Do we really want to become a country of big cities? In all the 700 languages of our country we have never needed words for air pollution, for slum or for unemployment. Do we wish to build the kind of country that needs these words? (Somare, 1973, p. 2).

Opposition to cities has been manifest in policies opposing migration to the towns, more often out of implausible attempts to preserve an aura of urban respectability by reducing the visible evidence of urban unemployment than out of any desire for rural development (Connell, 1997). In colonial times, there were firm administrative restrictions on rural-to-urban migration, particularly on the establishment of informal settlements in urban areas. In the post-colonial era, efforts to restrict rural-to-urban migration and curtail urbanisation continued as officials inherited the assumptions of colonial administrators, who perceived Melanesians as rural residents, and were reluctant to recognise both the necessity and inevitability of some degree of urbanisation.

In the past decade, anti-urban sentiments have again intensified and urban growth is increasingly being cast as a law-and-order issue. Evictions from informal settlements and intermittent calls for the colonial Vagrancy Act to be reintroduced have been prominent administrative responses to continued urban growth and growing law-andorder problems, especially as urban crime is now considered to be a major factor deterring foreign investment and business in Papua New Guinea (Levantis, 2000). Fierce opposition to urban growth and the violent nature of evictions signal the emergence of a disturbing trend towards the use of paramilitary style responses to increasingly complex and seemingly unmanageable urban 'problems'. Evictions are legitimised by a 'war on crime' rhetoric leading to knee-jerk reactions to urban development 'problems' without the need for recourse to considered and sustain- able urban planning policies. These new trends suggest that issues of urbanisation and urban development have become crime issues divorced from their socioeconomic and spatial contexts. This paper traces these shifts in the form of opposition to urbanisation, especially the increasingly violent nature of evictions, and links them to broader processes of change occurring in Papua New Guinea society, particularly the weakening of the state. We finally explore the implications for evicted residents, many of whom are from economically marginal rural areas and have been urban residents for many years.

\section{Urbanisation Policies during the Colonial Period}

Throughout Melanesia, but especially in Papua New Guinea, Solomon Islands and New Hebrides (Vanuatu), there were extensive attempts to regulate and control migration to towns in the pre-war and post-war years (Oram, 1970; Connell and Curtain, 1982; Connell and Lea, 1993; Jourdan, 1995; Rawlings, 1999). In the colonial era, regulations controlling employment and the mobility of wage labour were enforced and it was illegal for the indigenous Melanesian population to live in town without either a job or a permit. ${ }^{2}$ Restrictions on movements into towns in Papua New Guinea were introduced as early as 1914 with the Native Labour Regulations. Together with a range of other colonial legislation such as the Police Offenders Ordinance 1919-1939 (Papua), the Health Regulations 1922 (Papua), the Public Health Ordinance 19321938 (New Guinea) and building ordinances, these laws served to exclude the indigenous population from the urban landscape (Jackson, 1977). The Port Moresby community of 1921 was "predominantly white" (Inglis, 1974, p. 27). During the 1920s, whistles or bells sounded at $8 \mathrm{am}$ and 9pm; between these hours Melanesians were allowed to be in town. Through the 1950s, there were curfews on the presence of Melanesians in town. As late as 1970, Port Moresby was still described as a largely European town in 
Table 1. Urban centres, 1966-90

\begin{tabular}{lrrrr}
\hline & 1966 & 1971 & 1980 & 1990 \\
\hline Port Moresby (NCD) & 41848 & 76507 & 117991 & 194295 \\
Lae & 16546 & 38707 & 60708 & 80655 \\
Madang & 8837 & 15296 & 19718 & 27057 \\
Wewak & 8945 & 14982 & 19408 & 23224 \\
Mt Hagen & 3315 & 10621 & 13192 & 18977 \\
Goroka & 4826 & 8186 & 11067 & 18368 \\
Rabaul & 10561 & 12770 & 14581 & 18186 \\
Daru & 3663 & 5744 & 7149 & 8490 \\
Kimbe & - & 1172 & 4659 & 8363 \\
Vanimo & 512 & 1064 & 1752 & 7908 \\
Popondetta & 2139 & 4494 & 6343 & 7627 \\
Bulolo & 2724 & 4001 & 4500 & 7421 \\
Kavieng & 2142 & 3299 & 4769 & 6486 \\
Alotau & 525 & 2499 & 4311 & 6435 \\
Mendi & 1687 & 2435 & 4130 & 6192 \\
Lorengau & 2446 & 2890 & 3588 & 5804 \\
All urban & 110716 & 204667 & 297866 & 445488 \\
\hline
\end{tabular}

Sources: Connell (1985, p. 92) and Connell (1997, p. 189).

character with its political and economic spheres dominated by Europeans (Oram, 1970). Until the late 1970s, the towns in Papua New Guinea, and elsewhere in Melanesia, were essentially colonial administrative centres, a legacy that continued into the post-colonial era.

The various legislative restrictions for discouraging movement into cities and towns in Papua New Guinea were based on a set of assumptions regarding indigenous urban settlers. The most important of these were that urban settlers were temporary male sojourners whose families and 'true' homes were in the village and whose presence in town would lead to moral decline and law-andorder problems. These assumptions underpinned the restrictions on movement and also influenced wage structures, accommodation provision for employees and the practice of compulsory repatriation after a period of employment (see Ward, 1980; Connell, 1985; Ryan, 1989). Until 1972, for example, urban wages were calculated on the basis of supporting only a single man, and most migrants were housed by their employers who provided only single men's quarters (Curtain, 1980). The compulsory repatriation of em- ployees, a relic of the plantation economy and based on the assumption that workers were only temporary urban sojourners, also discouraged permanent urban settlement (Connell, 1985). Administrators at the time viewed squatter and informal settlements as transitory features of the urban landscape; indeed, as Ward (1998, p. 22) has pointed out

for colonial administrators in the late 1960s and 1970s it was comforting to think that urban in-migrants to towns, seen as potential problems, were just there temporarily.

Rapid urban growth in the late 1960s and especially in the 1970s challenged the assumption that urban migrants were there temporarily (Table 1). ${ }^{3}$ Moreover, the validity of the assumption of temporary urban migration was questioned as early as the mid 1960s when urban permanence was first acknowledged (see, for example, Ryan, 1966; Hitchcock and Oram, 1967; Oram, 1968; 1970; Ward, 1971; Young, 1977). These studies alluded to the prolonged residence periods of settlers in towns (Ryan, 1966; Hitchcock and Oram, 1967), the increasing number of children born in town and the 
Table 2. Rural and urban wage differentials

\begin{tabular}{cccc}
\hline & \multicolumn{2}{c}{ Minimum cash-equivalent wage, unskilled workers (\$/week.) } \\
\cline { 2 - 4 } Year & Rural & Urban & Differential (\%) \\
\hline 1961 & 4.61 & 6.00 & 30 \\
1964 & 4.61 & 6.50 & 41 \\
1967 & 4.86 & 6.50 & 34 \\
1970 & 4.86 & 7.00 & 44 \\
1973 & 5.90 & 13.80 & 134 \\
1976 & 9.50 & 29.00 & 205 \\
\hline
\end{tabular}

Source: Report of the Interdepartmental Committee on Incomes, Wages and Prices Policy, February 1974; cited in Jackson (1977, p. 24).

gradual balancing of sex ratios, all suggesting a more stable and permanent population (Ward, 1971). As Oram (1970, p. 63) noted at the time

It seems probable that over the next 20 years an increasing proportion of the urban population will come to regard Port Moresby as their permanent place of residence.

That prediction came true.

\section{The Lead Up to Independence}

Beginning in the 1960s, and into the immediate post-independence period, the gradual removal of restrictions on movement, relatively higher urban wages, employment growth and an expansion in government spending on welfare provision, increased the attraction of urban employment and residence. A more tolerant and less negative approach to urban life led to an official reluctance to enforce what was in effect a 'pass system' and a gradual reduction in the vigilance attached to searching out 'vagrants' (Oram, 1976), although intolerance of informal settlements in Port Moresby remained an issue. ${ }^{4}$ However, overall, somewhat more enlightened and realistic attitudes towards urbanisation in the period leading up to independence in 1975 tended to promote urban planning and rapid urbanisation (Forbes and Jackson, 1975; Connell, 1985). Increasing urban-rural wage differentials (Table 2) and the migration of women to urban centres also led to an expansion of urban family life and the development of a more stable workforce (Jackson, 1977).

At this time, the number of informal settlements in Port Moresby increased (Matwijiw, 1982) as government and private employers failed to provide sufficient housing to keep pace with the growing numbers of migrant workers and their families. Initially, nearly all the settlements were located on customary land with most residents being from the Port Moresby region and having some prior traditional trading relationship with the customary land-owning group (Oram, 1976). However, with the influx of migrants from elsewhere in Papua New Guinea, ties with customary land-owners weakened and more settlements began to emerge on unoccupied Crown Land (Oram, 1976). By 1979, 25 per cent of the indigenous population of Port Moresby lived in informal settlements (Matwijiw, 1982); that proportion has subsequently grown, being around 40 per cent at the start of the 1990s (Monsell-Davis, 1993) and perhaps as much as half at the end of the century.

The influx of migrants and the growth of 'illegal' settlements provided the impetus for renewed demands to control mobility and suggestions that a formal pass system be introduced. In the lead up to independence, although it was becoming more widely accepted by the administration that long-term settlement of migrants was inevitable, there 
was also unease and, at times, objection to the expansion of informal urban settlements (Oram, 1970). Administrators in Port Moresby, for example, planned to remove all migrants from customary lands on the grounds that the settlers had no security of tenure and the settlements were a "danger to health" (Oram, 1970, p. 55).

\section{Turning Full Circle in the Post-colonial Era}

Opposition to urbanisation re-emerged more strongly in the immediate post-colonial period as migration to towns increased and informal settlements expanded. At various times following independence and throughout the 1980s, most, if not all, urban authorities sought to evict squatters and/or the unemployed often under the guise of cleansing the city of criminals, the unemployed and 'illegal' occupiers of government and customary land. For example, opposition to migrants in the North Solomons Province had intensified to the extent that in 1977 and 1978 groups of squatters had been repatriated by plane to three Highlands provinces (Talyaga and Olela, 1978). Two years later, growing unemployment, urban crime and larger urban settlements were important issues in Port Moresby and Rabaul, where a provincial government committee was preparing a list of East Sepiks who wanted to return there or who should be sent home. In October 1979, one councillor called on the national government both to repatriate unemployed people from Port Moresby to their home province as a solution to the capital's law-and-order problem and to issue the employed with identification cards; the councillor argued, in what was to become a frequent refrain, that

the capital city of PNG should be a clean and respectable place to live in and should compare with major cities in other countries (quoted in Connell, 1985, p. 108).

In a number of different towns in PNG (alongside rural areas around Rabaul), there were pressures to repatriate migrants.
While little came of these attempts to 'clean up' urban areas, policy responses towards urban migration had quite quickly come full circle by the end of the 1970s. Instead of being directed by a colonial administration, they were now the preferred solutions of some provincial governments. Moreover, whilst some limited attempts were made to provide housing and improve conditions in urban settlements, the assumptions of colonial administrators regarding urban settlers appeared to have been inherited by many post-colonial officials. That is, urban migrants were temporary; their rightful place was the village; and, their presence in town would lead to moral decay and crime, and a rise in urban unemployment.

Attempts to deal directly with urban problems generally lapsed until the 1980s when provincial governments, especially in island provinces, once again began to take the initiative on this issue. The Island Regional Premiers Conference recommended several measures to deal with unemployment in the Islands Region and asked the national government "to give powers to Provincial Land Boards to evict squatters on traditionally owned land" (Arawa Bulletin, 3 April 1981). The national government made no response. Similarly, the North Solomons province made extensive efforts to remove squatters and formulate policies to encourage the employment of local workers rather than migrants, none of which was ever implemented (Connell, 1985, pp. 111-116). Particularly high wages in the province (as a result of mining) and a thriving regional economy stimulated continued migration; towns there and elsewhere continued to grow. Despite frustrations, there were few new attempts at policy formation or direct repatriation.

\section{Squatters and Crime}

In the past decade, opposition to informal settlements has further intensified as lawand-order problems have escalated sharply in urban Papua New Guinea. Newspapers regularly portray informal settlements as havens for the unemployed and criminal gangs. They 
are also commonly blamed for the breakdown in law-and-order and other social problems occurring in urban areas. Many believe that crime would diminish if the towns were closed to those who did not work there or did not have a 'valid' reason for being there. ${ }^{5}$ Hence, there have been strident calls for the repatriation of 'vagrants' and the 'unemployed' to their provinces of origin.

Although accurate criminal justice statistics on the nature and scale of crime are scarce, a range of evidence points to a rise in crime and violence in many towns (Dinnen, 2000; Levantis, 2000; Sikani, 2000). ${ }^{6}$ In Port Moresby, where most crimes are reported, statistics on serious crime from May to October 1997 included 33 murders, 31 attempted murders, 147 cases of rape, 47 cases involving grievous bodily harm, 44 unlawful wounding offences and 49 cases of abduction and kidnapping (Sikani, 2000, p. 41). At a national level, the annual rate of violent crime, which increased 20-fold from 1970 to 1990, is about 2000 incidents per 100000 people-figures that are 10 times higher than Australia and 6 times that of the nearby island nation of Fiji-and the probability of being a victim of crime is higher in Papua New Guinean urban centres than in such cities as Kampala, Rio de Janeiro and Johannesburg (Levantis, 2000, pp. 132-133). Fear of crime is justified.

Because law-and-order problems have grown in many urban areas of Papua New Guinea-although rural areas have not escaped parallel trends-anti-urbanisation sentiments can be identified in most provincial administrations and methods of controlling or discouraging migration have been a priority of numerous government and provincial leaders at various times during the past decade. During the 1990s, often under the guise of addressing the rapidly rising levels of urban crime, there have been large-scale 'squatter' evictions and attempts at repatriation by provincial authorities in most major cities and towns. Between 1997 and 1999, almost every major town in Papua New Guinea (including Port Moresby, Lae, Madang, Rabaul, Kokopo, Goroka and
Kimbe) has attempted 'squatter' clearances.

Urban evictions and clearances since the early 1990s have differed in several important respects from earlier attempts to control urbanisation. They are now on a larger scale, more violent and frequently involve alliances of local land-owners with government authorities and the police. The scale and violent nature of evictions was evident in Madang in $1997 / 98$ where the attempted eviction of approximately 8000 settlers represented almost 30 per cent of that city's 1990 population. Police from neighbouring provinces were called in and a total of 300 police were on stand-by. During the attempted eviction, many houses were bulldozed and Madang was declared a 'Fighting Zone' for 2 months. A 3-month liquor ban was also imposed (Post Courier, 1997h). Three years later, Madang went through much the same processes again.

In early 1998, when the US was bombing Iraq, the cartoon reproduced in Figure 2 appeared in the local press following calls by Police Commander Jeffrey Vaki to fight crime by clearing all 'squatter' settlements in Port Moresby. The cartoon exemplifies the increasingly heavy-handed approach to urban problems by provincial authorities and police. Many recent evictions have involved the raising and burning of houses, the killing of domestic animals and the destruction of food gardens. Urban settlers are being stripped of their assets to be left homeless (Post Courier, 1997g, 1998a, 1999a; The National, 1999). Such destructive eviction exercises appear to serve several purposes. They may be used for political point-scoring with local land-owners and business interests, to make other 'squatters' publicly aware and fearful of the government's 'crack-down' on crime and illegal settlements, and to make such settlements uninhabitable and extremely difficult to re-establish. The lack of compassion towards informal settlers and the violent nature of recent evictions have raised concerns amongst some community leaders about human rights violations (Post Courier, 1998a, 1998b, 1999c). Such voices, however, do little to counter the dominant discourse 


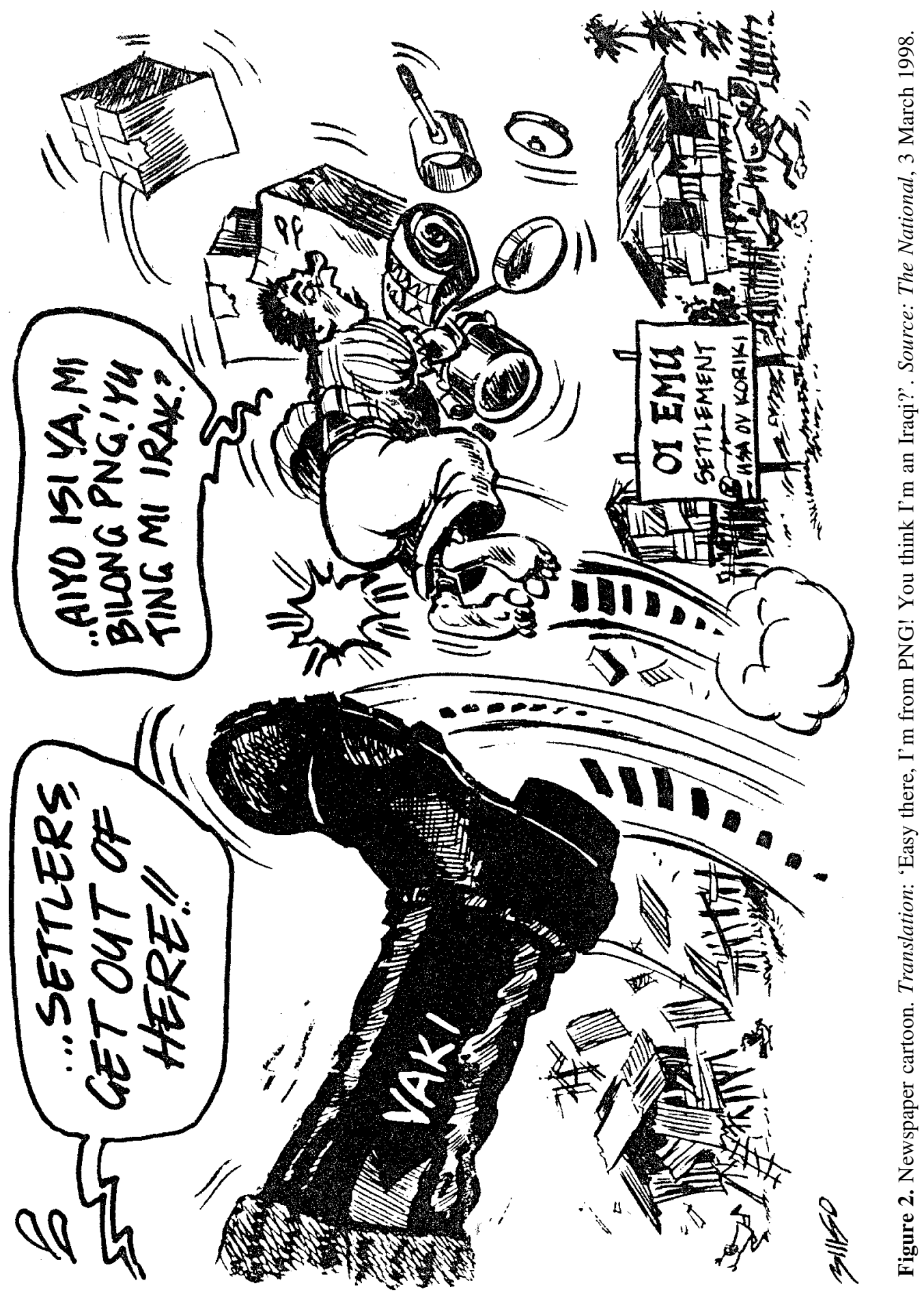


amongst provincial authorities and police that such settlements are repositories of criminals and the unemployed.

There is no evidence that criminals are more numerous in settlements, yet it is widely believed that this is so; hence, the claims of settlers for financial supportthrough service schemes and social amenity provision-are less likely to be met and are usually routinely rejected. Settlements, unemployment and crime are discursively linked by politicians and police spokespeople and "monotonously repeated in the daily press" alongside routine contextualisation of the "inevitable consequences of urban migration and poverty" (Goddard, 2001, p. 4) that invariably lacked substance. At the very least, there is a considerable diversity of settlements and settlers.

This generally antagonistic approach to the issue of urbanisation has contributed to an unwillingness to countenance the upgrading and acceptance of settlements that might lead to a reduction of urban problems. For example, to discourage migration, infrastructural costs of urban development have been passed on to urban consumers in higher electricity and water charges and, during the 1980s, the National Housing Commission was instructed to do without government subsidies (Connell, 1997). Such policies tended to place urban services further beyond the reach of the majority of the urban population, to an extent that is much greater than elsewhere in the Pacific region (Connell and Lea, 2001). Moreover, there was little effort to understand the circumstances of urban settlers and the factors contributing to increased urbanisation. Violence and destruction have become instruments of urban planning as urban problems become increasingly complex and unmanageable.

A disturbing trend in these evictions is the collaboration of local land-owners with local/ provincial authorities and police in actions to evict settlers. ${ }^{7}$ Increasingly, indigenous landowners and ethnic groups are seeking government support to repatriate settlers and/ or are participating directly with officials in eviction exercises. For instance, in the March
1999 evictions from the East New Britain capital of Kokopo, more than 100 men from the nearby village of Ulagunan assisted police and officers from the lands division and local government to evict over 200 people. Armed with bush knives, they assisted with the destruction of settlers' houses, food gardens, fruit trees and betel nut palms and the killing of settlers' pigs, dogs and chickens (Post Courier, 1999a; 1999b). In another similar case in March 1999, Central Provincial Governor Ted Diro signed an agreement with land-owner representatives from Kilakila and Koboka villages near Port Moresby that granted provincial police the authority to evict settlers from these village lands (Post Courier, 1999d). While the agreement gave back to land-owners control of their land, it also allowed police to evict squatters from along the Magi and Hiritano highways which lead out of Port Moresby (Post Courier, 1999d). A year later, after there had been attacks on travellers on the highway, Diro called on the national government to remove all squatter settlements in the capital (Post Courier, 2000c).

Such alliances between the state and landowners have tended to inflame ethnic tensions, pitting local land-owners against migrants from distant provinces, which legitimises and reinforces official antagonism towards settlers and may also provide an ideal solution for land-owners wishing to manage their lands differently. Many of the initial settlers had informal tenancy arrangements with land-owners and, in some of the earliest settlements, settlers had long-standing trading relationships with land-owners (Oram, 1976; Goddard, 1998). These relationships with customary land-owners and tenancy arrangements are undergoing change in the new social and economic urban context. Now that the commercial value of their land has increased, alliances with state authorities against settlers may provide land-owners with the means to realise the potential of higher commercial land values. The mutually beneficial relationships now developing between land-owners and the state can be legitimised under the rhetoric of 'fighting crime', 
thus enabling land-owners to repossess nowvaluable commercial land while providing the state with more effective control over urban land management.

The rhetoric of responding to crime can be a subterfuge for the implementation of urban policies by state authorities. While crime issues were prominent in the justification for the attempted eviction of over 8000 settlers from Madang in 1997, an official from the Provincial Administrator's office admitted that

The government decided to take this stand because of the real shortage of land for town expansion and the business boom already taking place (Post Courier, 1997c).

In Madang, some portions of state land titles occupied by 'squatters' had already been licensed to businesses for industrial development, but progress had stalled because settlers resisted leaving. At the time, the Madang Governor, Jim Kas, was reported as saying that "illegal settlers on land belonging to the state must pave the way for development investors" (Post Courier, 1997e), a call again repeated there three years later (Post Courier, 2000d). While the main eviction exercise became stalled in the Waigani National Court during 1997 and 1998, Bilia Point settlement containing 70 houses near Madang Harbour was demolished in November 1998 following a court order sought by a Madang-based company that had been granted a licence to the land (Post Courier, 1998g). The 'war on crime' rhetoric thus legitimised knee-jerk responses to urban development issues without the need for sustained urban planning policies and strategies.

Alongside these recent attempts at urban clearances, there have again been several calls to reintroduce the Vagrancy Act and other policies to restrict freedom of movement between provinces. At the 1998 Governor's Summit in Port Moresby, several provincial governors proposed that the national government review and reintroduce the Vagrancy Act to control rural-to-urban mi- gration and thus curb rising levels of urban crime (Post Courier, 1998e). The private sector has also been urging the government to address the growth of informal settlements and the rise in urban crime by reintroducing the Vagrancy Act and introducing an identity card system (Post Courier, 1997f), both issues being considered further by the Minister of Justice in 2000 (Post Courier, 2000a). ${ }^{8}$ One consequence was an absolute ban being placed on the construction of new settlements in Port Moresby (a ban that had been breached within weeks of its implementation).

These examples illustrate the growing trend to cast urbanisation and rural-urban migration as law-and-order problems. Narratives of violence and cleansing the city of criminals and illegal squatters on state and customary land are by far the dominant themes in the discourse of urban management and control. With the blurring of crime and urban issues, urban land management strategies are now infused with the same militaristic strategies used in dealing with crime more generally. Speaking to the Chamber of Commerce and Industry and the Papua New Guinea Chamber of Mines and Petroleum, the NCD/Central Police Commander, Jeffrey Vaki in reference to 'squatter' clearances around Port Moresby, described the police's role as "fighting a war" to "clean up" the city (The National, 1998).

The violent nature of urban management appears to be part of what Dinnen (1999) has identified as a more general trend in Papua New Guinea of relying increasingly on militaristic solutions to internal security problems such as crime and social disorder. For example, when a police sergeant was slain during a robbery in Madang, the police retaliated by burning and ransacking more than 50 houses and several tradestores in the settlement in which the alleged offenders resided (Post Courier, 1997a; 1997b). One settler said "We are being terrorised at night by criminals and during the day by police" (Post Courier, 1997a). A growing reliance on emergency measures such as states of emergency, joint police and military opera- 
tions, curfews, special police units and the regular use of 'shoot-to-kill' orders all indicate that violence is increasingly used as a tool to deal with internal security issues (Dinnen, 1999). ${ }^{9}$ These 'quick fix' strategies, Dinnen argues, reflect the weakening of the state which, in combination with an autocratic leadership style, have had a debilitating effect on government agencies.

Coercive solutions offer the prospect of speedier outcomes than those likely to flow from protracted negotiations or cumbersome bureaucratic processes directed toward policies addressing underlying causes (Dinnen, 1999, p. 290).

Thus, there is little space for wider discussion of issues of urbanisation and development within the broader spatial context of rural and urban change. Issues of urbanisation and urban development have become crime issues divorced from their socioeconomic and spatial contexts.

\section{Urban Resident or Rural Visitor?}

Another theme in the state discourse on urbanisation in Papua New Guinea that serves to legitimise evictions, and which harks back to the early colonial period, is the view of the village as being the rightful place for Papua New Guineans-a place that offers a cleaner, more dignified and more 'traditional' way of life. The rhetoric of self-reliance, dignity and the village providing a hygienic, productive, honest and fulfilling life is strong in the discourse of provincial and government leaders

My plan to eject settlers [in Lae] is a genuine one for the sake of my people who want a trouble free environment for their children ... As for Papua New Guinea which has a large area of land, I do not see why people should move from province to province. I am sure there are better things to do in their own villages or towns (Morobe Premier The Times of Papua New Guinea, 6 June 1991; quoted in Connell, 1997, p. 210).
Not surprisingly, this was not the settlers' perception. At the same time, in Rabaul, illegal settlers were ordered to be evicted for similar reasons. The East New Britain Premier stressed that the exercise was being undertaken for the good of both the province and the settlers

We want to help the settlers so that they can have dignity and that they can grow their own cash crops in their respective villages. Villages are still the best and least expensive places to live. Furthermore we want settlers to understand that they were not born to be slaves in towns. However they are making themselves slaves (The Times of Papua New Guinea, 29 August 1991; quoted in Connell, 1997, p. 210).

In another example, Police Chief Geoffrey Vaki, referring to squatters in illegal settlements in Port Moresby and elsewhere, said that

Papua New Guinea was oriented on Melanesian traditions of subsistence farming and wantok system, and there should be no excuse for people seeking land for resettlement. I don't think people should live in such undignified conditions as Baruni and the old parliament since we have vast land back in the villages where people can resettle and make gardens. ... Our ancestors never lived in bacteria-infested areas and we are a country proud of our cultural heritage. No one should tell me they have no place to resettle (Post Courier, 1998d).

In 2000, all Members of Parliament from outside Port Moresby were urged to "encourage their $[s i c]$ unemployed people to return home and start projects in their provinces" (Post Courier, 2000b). These kinds of statement emphasise the view that the urban migrant's 'real' home is the village where a communal, subsistence lifestyle provides for a wholesome existence. This widespread constructed view of an idyllic rural life, a 20th century 'merrie Melanesia', 
allows the urban migrant to be portrayed as temporarily out of place and in an environment lacking the traditions, morals and positive societal values of rural communities. Thus the urban migrant is prone to all the negative consequences of an urban life-a squalid, morally impoverished existence and crime-ridden lifestyle. The task then is a moral one, to remove these people from the urban landscape by encouraging them to return home to lead 'fulfilling' and productive lives.

\section{Back to the Land?}

The assumption that migrants can return 'home' is highly questionable for several reasons. Periods of urban residence are increasing as many more people are born in town and no longer maintain exchange relationships with 'home'. Further, and unacknowledged by government, economic conditions in many rural areas are worsening such that it would be extremely difficult, if not impossible, for many migrants to re-establish themselves and their families in their 'home' villages. We examine each of these points below.

The assumption that people are temporary urban residents fails to recognise the changing context of rural-to-urban migration in Papua New Guinea. Migration to towns is increasingly characterised by long-term family migration and not by short-term circular migration of young single males. More balanced sex ratios in town suggest a more permanent and stable urban populationtrends that were apparent by the 1971 census. Although in-migration remains a significant component of urban growth in Papua New Guinea (Connell and Lea, 1993), natural increase is slowly assuming greater importance in the growth of informal settlements.

The assertion that contemporary urban settlers are temporary sojourners in the urban landscape also fails to recognise the very long time many of these settlements have been in existence, and that many residents have now lived most, if not all, of their lives in towns and cities. Growing numbers of residents in informal settlements and towns are second- or third-generation urbanites with few if any ties to their 'home' villages and, therefore, have limited opportunities beyond the town or city (Oram, 1970; Zimmerman, 1973; Townsend, 1977; Morauta and Ryan, 1982; Connell, 1985; Ryan, 1993; Kaitilla, 1994; Ward, 1998). In the late 1970s, Garnaut et al., (1977) recognised that around a quarter of the children born in Port Moresby, Lae and Rabaul had never visited their village 'homes'. In a study conducted in the early 1980s, over half of the Toaripi (Gulf) migrants in Nine-Mile, Port Moresby, had never lived in 'their village', had none of the 'survival skills' for village life (or land or close kin there) and hence were likely to remain urban residents (Chao, 1985). More recently, many of the residents involved in the 1997 Madang evictions had been living there for 40 years or more. Their commitment to urban living was evident in the fact that they had begun to bury their dead in town rather than sending the corpses 'home' for burial. ${ }^{10}$ In the lead up to the evictions, they petitioned the government for coffins so that the exhumed remains of deceased relatives could be returned to their home villages for reburial (Post Courier, 1997d).

Long-term demographic trends in Papua New Guinea invalidate assertions that people are temporary sojourners who can return home. The 1973/74 urban surveys in Papua New Guinea first introduced the concept of 'dispossession' amongst urban residents; the 'dispossessed' being those who lacked access to the resources of the village economy, mainly because of insufficient tenure rights (Garnaut et al., 1977). Other studies at the time, and more recently, have reported the growth of an 'urban proletariat' comprised of permanent migrants to towns dependent on wage employment (for a summary, see Connell, 1985, pp. 97-98; Ryan, 1989). Much of the urban proletariat lack a subsistence alternative to urban employment either due to their villages being absorbed into expanding urban areas, or because they had in- 
sufficient resources to enable them to maintain close ties with home. The most vulnerable migrant groups, with few opportunities to access resources at 'home', are from poor regions: they lack capital for travel, cannot distribute money and gifts in rural areas and hence must retain their commitment to a precarious urban existence (Connell and Lea, 1993, 1994). Many informal urban settlements in contemporary Papua New Guinea are made up of growing numbers of the urban dispossessed and an urban proletariat who no longer have access to village land and have few, if any, ties to their 'home' villages.

Ties with 'home', especially the maintenance of indigenous exchange relationships, are very important for the resumption of village resource rights for returning migrants. Migrants who, for whatever reasons, do not maintain these exchange relationships during their absence or fail to fulfil social obligations risk foregoing access rights to land and other resources (see Garnaut et al., 1977; Morauta, 1981; Curtain, 1980; Morauta and Ryan, 1982; Carrier and Carrier, 1989; Curry and Koczberski, 1999). When Member of Parliament for Moresby South, Lady Carol Kidu, helped to repatriate a group of 42 young men from Two Mile Hill settlement, she sent a settlement leader with them to explain to villagers that these young men did not have money with them to distribute at 'home'. She requested that the villagers accept them as they were (Post Courier, 1998h). Often, however, these people join the ranks of the 'urban dispossessed' (Morauta and Ryan, 1982). A recent example was the evacuation of 8000 Sepiks following the 1994 Rabaul volcanic eruption (Neumann, 1997). Many evacuees found they were unwelcome in their home villages and some found their land had been taken over by others. Village relatives often asked "Why should we give you food or let you sleep in our house ... after all you never thought of us when you lived in comfort in Rabaul"-a reference to their perceived failure to fulfil exchange obligations. The majority of those repatriated had returned to East New Britain by the beginning of 1996. After years of village absence, they had become 'foreigners' in their home villages and 'home' was now Rabaul.

Thus, while some urban migrants may return home, for many of them, and especially the poorest, the return option is too difficult, or impossible, even if it were sought. Such urban residents are in a very vulnerable position given the growing intolerance of urban settlers. They may have little alternative but to join the ranks of the urban dispossessed, constantly threatened by eviction and harassment by the state authorities with the tacit or active support of local landowners. Their dire predicament is reflected in the words of one resident whose house and belongings were destroyed in the 1999 evictions in Lae.

We have lived here for more than 15 years; our children were born here; some have married and are living with their families here. We do not know where to go and we do not know where we are going to sleep tonight now that our homes have been burnt to the ground (The $\mathrm{Na}$ tional, 1999).

The growing pool of dispossessed urban settlers is evident in many of the recent evictions in Papua New Guinea where evicted settlers have attempted to re-establish themselves at the same site after the eviction or have surfaced at other urban settlements. For instance, in the October 1999 evictions in Lae in which up to 100 families were evicted, one settler claimed that this was the third time that their houses had been burnt down and their property destroyed (The $\mathrm{Na}$ tional, 1999). Following the Kokopo evictions in early March 1999, Rabaul's acting town manager, Ephraim Wartoro, reported a sudden influx of 'squatters' to Rabaul. Many of these arrivals had originally moved to Kokopo after the 1994 volcanic eruption in Rabaul and now were returning to Rabaul after their eviction from Kokopo

There is a reported heavy presence of settlers at Torch Bearer [Rabaul], and we 
cannot single out any group, but we believe these were the same people who left Rabaul during the eruptions, went to Kokopo and are now coming back (Wartoro; cited in Post Courier, 1999d).

Following the 1994 evictions of 2000 people in Rabaul, the neighbouring West New Britain authorities were concerned about the large numbers of evicted people seeking refuge in West New Britain (Post Courier, 1994). In 1998, blockholders at Poro resettlement scheme in West Sepik urged the Lands Department to release and sub-divide further land to accommodate people displaced by evictions from settlements and towns in West New Britain, Rabaul, Madang and other urban centres (Post Courier, 1998c; 1999e). Evictions thus pose a burden for other nearby urban centres (where these exist), for 'home' areas (where land is scarce) but, above all, for the urban residents themselves.

\section{Rural Migration}

The expectation that evictions and other policies of controlling migration will significantly stem the flow of migrants to urban areas, or encourage people to return to their home villages, ignores on-going problems in rural areas, especially issues of landlessness, marginalisation and the growing economic disparities between urban and rural Papua New Guinea. As a World Bank report recognised almost 20 years ago

Much of the migrant population in urban settlements originates in provinces with either relatively high population densities or relatively low agricultural potential or both. It is difficult to see how these areas can be developed sufficiently and rapidly enough to reduce migrant flows significantly and, furthermore, the cost of developing these regions may well be above the cost of development elsewhere in the country and will, therefore, run into significant trade-off problems (World Bank, 1981, p. 9; quoted in Connell, 1985, p. 95).
In the subsequent two decades, rural conditions in many parts of Papua New Guinea have deteriorated and rural and urban disparities have increased. Many rural people, for example, still do not have adequate access to a regular income, health services, schools or road networks and transport facilities. For example, health services have been deteriorating since the 1980s. Since 1990, half of all rural aid posts have closed because of staff shortages and the lack of essential medical supplies. In the mid 1990s, the Minister for Health reported that 60 per cent of health facilities in the provinces were closed, unstaffed or had no medicines or equipment (Connell, 1997). The effects of these closures are reflected in a sharp rise in infant mortality rates. For instance, in Eastern Highlands Province, the infant mortality rate increased from 55 per 1000 livebirths in 1980 to 100 in 1994 (Duke, 1999). Hence, urban-rural inequalities are widening and rural Papua New Guinea is characterised by high infant mortality rates, low educational levels and incomes and poor standards of living (Table 3).

Growing socioeconomic inequalities between rural and urban areas will continue to fuel migration from poor and densely populated rural areas as rural villagers seek to escape rural poverty and, increasingly, landlessness (Curry and Koczberski, 1999). Attempts to curtail or reverse migration flows from rural areas, especially from depressed rural regions, will therefore be extremely difficult. As Marion Ward succinctly stated in reference to urbanisation in the 1960s: "to attempt to stem the flow of urban migration is ... an exercise in Canutian logic" (Ward, 1970, p. 53). Policies aimed at controlling rural-to-urban migration are unlikely to succeed because they fail to recognise the role and resilience of social and kinship networks in facilitating migration (Curry and Koczberski, 1998). Such networks lessen risks associated with migration as new arrivals in towns and cities can anticipate support and assistance from kin. One of the key elements of these networks is 
Table 3. Urban-rural disparities in Papua New Guinea, 1996

\begin{tabular}{llcc}
\hline & Unit & Urban & Rural \\
\hline Infant mortality rate (per 1000 births) & Number & 33.7 & 86.6 \\
Households connected to electricity & Percentage & 59.2 & 3.2 \\
Population with no formal education & Percentage & 24.4 & 50.5 \\
Households possessing a motor vehicle & Percentage & 19.9 & 1.4 \\
Real minimum wages (1977 prices) & Kina pw & 25 & 9 \\
\hline
\end{tabular}

${ }^{\text {a }}$ Figures are for 1992.

Source: Bank of Papua New Guinea (1998, p. 14)

their capacity to sustain population flows independently of objective economic conditions at origin and destination. They can operate largely outside the arena of policy makers, and thus migration flows along networks are notoriously difficult to influence by policy intervention, let alone to stop. Almost all past attempts to prevent such movements have failed. The networks are enormously resilient, even in the face of the most vigorous and draconian actions of governments. Hence, once established, they become very strong forces for perpetuating streams of movements (Hugo, 1997, p. 282).

Consequently, attempts to reverse rural-urban migration in African and Asian countries have thus similarly failed as they fly in the face of contexts where the decentralisation of economic activity has been difficult if not impossible, rural development schemes have been poorly implemented through lack of administrative resources and conflicts between state and regional authorities and ethnic tensions have surfaced (Riddell, 1978; Peek and Standing, 1979; Standing, 1979; Connell, 1987). Few schemes have been implemented in recent years.

Widening economic disparities between urban and rural Papua New Guinea mean that the pressures to migrate will continue to build despite the 'Canutian logic' of current attempts to stem urbanisation. Increasing numbers of rural villagers have little option but to accept the risk of a precarious urban existence. Many of these people will find themselves swelling the ranks of the urban dispossessed, as an increasingly alienated and discontented group. Narratives of violence and the clean city, the discursive strategies of élite opposition to the grassroots, mark such settlers with their rural origins, as being much like those in shantytowns elsewhere

a kind of modern-day plague, an unruly cancerous growth, an infectious epidemic inflicted on the once healthy and sound social body of the community (ScheperHughes, 1992, p. 94; quoted in Goddard, 2001, pp. 3-4).

\section{Conclusion}

Urbanisation has continued unabated despite an entrenched anti-urbanism through most of the colonial and post-colonial periods, and there is no indication that urban growth will falter in the foreseeable future. Recent attempts to find solutions to urban growth and rural-to-urban migration have focused almost entirely on harsh punitive measures as urbanisation is increasingly represented as a lawand-order issue. However, authoritarian or coercive controls on migration address some symptoms of urbanisation (crime, unemployment and the development of illegal settlements), rather than the causes of resource misallocation and regional economic disparities (Oberai, 1979, p. 242). Two decades ago, Denoon observed that

The attraction of closed towns is very obvious ... With one bound we rid ourselves of poverty, ignorance and disease; modern towns shed their nasty reminders 
of underdevelopment ... Closed towns are the millennial dream of the propertyowning, rate-paying middle class (Denoon, 1980, p. 283).

Denoon has reviewed the rationale for closing Papua New Guinean towns and concluded, by analogy, that

urban problems may be the manifestation of rural underdevelopment [so that] the mere closure of the towns will merely complicate the problem by obscuring it (Denoon, 1980, p. 288).

Closing towns would therefore be more likely to worsen rural poverty and stress rural-urban inequalities. Squatters are part of an entrenched constituency in post-colonial Melanesia that cannot be sorted out by attempts at social engineering of a kind that might have been possible in former times. To advocate repatriation is to assume, erroneously, that the social, political and institutional means are present. These modern fears and concerns have contributed substantially to limited interest in and expenditure on the poorest parts of cities.

Despite official concerns over the management of urbanisation, alongside an expressed focus on rural development, there have been few genuine attempts to plan urban development adequately by, for example, encouraging the growth of small rather than large towns, which might provide alternative growth centres and enable more efficient market systems. Similarly, there has been widespread opposition to the growth of informal-sector economic activities even including markets, rather than perceiving this as a means of contributing to resolving urban employment problems (Connell, 1997; Levantis, 2000). Even if some violent evictions have been partly successful in stemming the flow of migrants into the cities or encouraging some urban people to return to their rural villages, the underlying problems remain. A 'bulldozer' approach to informal urban settlements has not stemmed the flow of migrants, particularly from economically depressed rural areas. Hence, governments must acknowledge contemporary rural and urban conditions in Papua New Guinea, that now involve the existence of large numbers of second- and third-generation urbanites without access to village land, the inaccessibility of formal-sector housing to many urban residents, the large and expanding pool of urban dispossessed and the likelihood of a continual flow of the rural disadvantaged to urban areas. These trends are now entrenched, and the use of state violence to address urban 'problems' merely creates further dissent and alienation, and destabilises the state's already fragile social and economic infrastructure. Without more sensitive urban and rural policies, recent draconian responses to urbanisation are of limited utility.

The increasing use of violence, not only as a tool to manage urbanisation but more generally to address the country's development problems, has been recognised by observers as reflecting a weakening state capacity to deal with social, political and economic issues, especially problems related to internal dissent (Dinnen, 1999; O'Collins, 2000). It also reflects the limited capacity of a weak state to achieve 'desired' policy outcomes, primarily the generation of employment opportunities and service provision (despite an urban bias in resource allocation). Violent raids of short duration on informal settlements are easier than formulating complex policies relating to urban planning or policies that address the causes of urbanisation-such as resource misallocation, rural poverty and regional economic disparities. Ironically dramatic, code-named police raids and the sporadic evictions of settlers serve no wider purpose "than a show of governmental and police competence in the struggle to achieve law-and-order" (Goddard, 2001, p. 25) that is at variance with both the location of crime and criminals and the weakness of the state in its inability to stimulate economic and social development. Moreover, they also pander to entrenched urban interests, thus emphasising intraurban inequalities. The reliance on a range of 'quick-fix' solutions that increasingly involve state-sponsored violence 
is leading to a situation where people are coming into repeated conflict with a range of state institutions. Hence, there is very real potential for a serious breakdown of civil society in particular areas of Papua New Guinea. Indeed, potential flashpoints include not only urban areas, but all areas where there have been high levels of migration-mine sites, plantations and land settlement schemes (notably those based on export cash crops like oil palm) where different cultural groups reside on alienated land. The sharpening of ethnic identities now occurring at such sites of high inmigration appears to be embedded within broader processes of socioeconomic change that are contributing to the tensions now surfacing between land-owners and settlers in different parts of Melanesia, including Fiji and Solomon Islands (where recent political violence has ensued). Urbanisation, without adequate policy formation, has entrenched cultural division, emphasised established ethnic identities, fostered intraurban inequality, exacerbated social problems in growing urban centres and hampered the task of stimulating economic and social development.

\section{Notes}

1. First estimates from the 2000 census of the populations of Papua New Guinea's two largest cities, Port Moresby and Lae, put them at around 245000 and 120000 respectively.

2. The indigenous population of Port Moresby before 1942 consisted of inhabitants of urban villages which were outside the town boundary and migrant workers who resided in accommodation provided by their employers (Oram, 1970).

3. At the 1971 census, there were only two towns in Papua New Guinea with populations over 20000 (Connell, 1997), and less than 10 per cent of the population lived in towns and cities in the early 1970s.

4. For example, the Vagrancy Act was enforced at least as recently as 1973 .

5. It has been estimated that 15 per cent of the urban workforce in Papua New Guinea earn a livelihood through criminal activity. The average earnings of those engaged in criminal activities tend to be higher than those of people in unskilled formal employment (Levantis, 1997).

6. A critical problem with crime statistics in Papua New Guinea is that most crimes committed are not reported in criminal justice statistics or police records; statistics have not been publicly released since 1990 (Dinnen, 2000; Levantis, 2000). Similarly, although several observers report a rise in the use of police firearms and military weapons in criminal activities and a greater incidence of unprovoked violence from the police, no reliable figures are available.

7. While crime issues may legitimise the eviction of settlers, many of the conflicts between settlers and land-owners appear to be embedded within broader ethnic tensions now surfacing between land-owners and settlers in different parts of Melanesia (for example, Fiji and Solomon Islands). To date, there has been little research on these tensions in urban Papua New Guinea, but recent events on informal urban settlements and resettlement schemes in West New Britain and Popondetta reveal that tensions between land-owners and migrants are set within complex historical and political backgrounds that will not be resolved easily (Curry and Koczberski, 1999).

8. The Post Courier (1998f) reported a motion put to Parliament to control urban drift into Port Moresby. The motion failed to be passed by the majority of members.

9. According to the Melbourne Sunday Age (2000) the Papua New Guinea government is considering combining the Defence and Police forces by establishing a single paramilitary unit.

10. The spirits of the deceased are believed to play an important role in the lives of their living kin and, therefore, burial sites must not be too far from the settlements of living kin.

\section{References}

Bank of Papua New Guinea (1998) Money and Banking in Papua New Guinea. Port Moresby: Bank of Papua New Guinea

CArrier, J. G. and CArrier, A. H. (1989) Wage, Trade, and Exchange in Melanesia: A Manus Society in the Modern State. Berkeley, CA: University of California Press.

Chaо, M. I. P. (1985) Life in a squatter settlement, Catalyst, 15, pp. 168-207.

Connell, J. (1985) Migration, employment and development in the South Pacific: Country Report No. 14 Papua New Guinea. Noumea: South Pacific Commission and International Labour Organisation. 
ConNell, J (1987) Migration, rural development and policy formation in the South Pacific, Journal of Rural Studies, 3, pp. 105-121.

Connell, J. (1997) Papua New Guinea: The Struggle for Development. London: Routledge.

Connell, J. and CuRTAin, R. (1982) Urbanisation and inequality in Melanesia, in: R. J. MAY and H. Nelson (Eds) Melanesia: Beyond Diversity, pp. 461-500. Canberra: Australian National University Press.

Connell, J. and Lea, J. (1993) Coping with urbanisation in Melanesia, Development Bulletin, 27, pp. 11-15.

Connell, J. and LeA, J. (1994) Cities of parts, cities apart? Changing places in modern Melanesia, The Contemporary Pacific, 6, pp. 267-309.

Connell, J and LeA, J. (2001) Urbanisation in the Island Pacific. London: Routledge (in press).

Curry, G. N. and Koczberski, G. (1998) Migration and circulation as a way of life for the Wosera Abelam of Papua New Guinea, Asia Pacific Viewpoint, 39, pp. 29-52.

Curry, G. N. and Koczberski, G. (1999) The risks and uncertainties of migration: an exploration of recent trends amongst the Wosera Abelam of Papua New Guinea, Oceania, 70, pp. 130-145.

Curtain, R. (1980) The structure of internal migration in Papua New Guinea, Pacific Viewpoint, 21, pp. 42-61.

Denoon, D. (1980) Closing the towns: solutions or evasions, in: R. JACKSON, P. BATHO and J. ODONGO (Eds) Urbanisation and its problems in Papua New Guinea, pp. 283-289. Port Moresby: University of Papua New Guinea.

DinNEN, S. (1999) Militaristic solutions in a weak state: internal security, private contractors, and political leadership in Papua New Guinea, The Contemporary Pacific, 11, pp. 279-304.

DinNEN. S. (2000) Threatening the state: crime and public order in Papua New Guinea, in: B. Boeha and J. McFarlane (Eds) Australia and Papua New Guinea. Crime and the Bilateral Relationship, pp. 65-74. Canberra. Australian Defence Force Academy.

Duke, T. (1999) Decline in child health in Papua New Guinea, Lancet, 354, pp. 1291-1294.

FORBES, D. and JACKSON, R. (1975) Planning settlements: the example of Ranuguri, Port Moresby, Australian Geographer, 13, pp. 5456.

Garnaut, R., Wright, M. and Curtain, R. (1977) Employment, incomes and migration in Papua New Guinea towns. Monograph No. 6, IASER, Port Moresby.

GODDARD, M. (1998) Off the record: village court praxis and the politics of settlement life in Port
Moresby, Papua New Guinea, Canberra Anthropology, 21, pp. 41-62.

GodDARD, M. (2001) From rolling thunder to reggae: imagining squatter settlements in Papua New Guinea, The Contemporary Pacific, 13, pp. 1-32.

Hiтchсоск, N. (1967) Migration and employment, in: N. E. HiтcHCOCK, and N. ORAM (Eds) Rabia Camp: A Port Moresby Migrant Settlement, pp. 47-121. New Guinea Research Bulletin, 14, Canberra: New Guinea Research Unit.

Hitchсоск, N. E. and Oram, N. (Eds) (1967) Rabia Camp: A Port Moresby Migrant Settlement. New Guinea Research Bulletin No. 14. Canberra: New Guinea Research Unit.

Hugo, G. (1997) Asia and the Pacific on the move: workers and refugees, a challenge to nation states, Asia Pacific Viewpoint, 38, pp. 267-286.

Inglis, A. (1974) Not a White Woman Safe: Sexual Anxiety and Politics in Port Moresby 19201934. Canberra: Australian National University Press.

JACKSON, R. (1977) The growth, nature and future prospects of informal settlements in Papua New Guinea, Pacific Viewpoint, 18, pp. 22-42.

JouRDAN, C. (1995) Stepping-stones to national consciousness: the Solomon Islands case, in: R. J. FosTer (Ed.) Nation Making: Emergent Identities in Postcolonial Melanesia, pp. 127149. Ann Arbor, MI: University of Michigan Press.

KAITILLA, S. (1994) Urban residence and housing improvement in a Lae squatter settlement, Papua New Guinea, Environment and Behaviour, 26, pp. 640-668.

LeVAntis, T. (1997) Urban unemployment in Papua New Guinea-it's criminal, Pacific Economic Bulletin, 12(2), pp. 73-84.

Levantis, T. (2000) Crime catastrophe-reviewing Papua New Guinea's most serious social and economic problem, Pacific Economic Bulletin, 15(2), pp. 130-142.

Matwisiw, P. (1982) Urban land problems in Port Moresby, Papua New Guinea, Tijdschrift voor Economische en Sociale Geografie, 73, pp. 286-294.

Melbourne Sunday Age (2000) PNG defence in tatters, 30 April.

Monsell-Davis, M. (1993) Urban exchange: safety net or disincentive? Wantoks and relatives in the urban Pacific, Canberra Anthropology, 16, pp. 45-66.

MoRAuTA, L. (1981) Mobility patterns in Papua New Guinea: social factors as explanatory variables, in: G. W. JONES and H. V. Richter (Eds) Population Mobility and Development: Southeast Asia and the Pacific, pp. 205-228. Canberra: Australian National University. 
Morauta, L. and Ryan, D. (1982) From temporary to permanent townsmen: migrants from the Malalaua district, Papua New Guinea, Oceania, 53, pp. 39-55.

The National (1998) Throw settlers out, says Vaki, 2 March.

The National (1999) Fifty houses razed in eviction drive, 15 October.

National Statistical Office (1994) Report on the 1990 National Population and Housing Census in Papua New Guinea. Port Moresby: Government of Papua New Guinea.

Neumann, K. (1997) Nostalgia for Rabaul, Oceania, 67, pp. 177-193.

OBerAi, A. S. (1979) State policies and internal migration in Asia, International Labour Review, 120, pp. 231-244.

O'Collins, M. (2000) Law and order risks in Papua New Guinea: perceptions and strategies. Unpublished paper presented at a Political and Social Change Seminar, Australian National University, Canberra, 10 May.

Oram, N. D. (1968) The Hula in Port Moresby, Oceania, 39, pp. 1-35.

ORAM, N. D. (1970) Indigenous housing and urban development, in: J. V. LANGMORE and N. D. Oram (Eds) Port Moresby Urban Development, pp. 45-88. New Guinea Research Bulletin 37. Canberra.

Oram, N. (1976) Colonial Town to Melanesian City: Port Moresby 1884-1974. Canberra: Australian National University Press.

Papua New Guinea (1978) The National Public Expenditure Plan 1978-1981. Port Moresby: National Planning Office.

Peek, P. and Standing, S (1979) Rural-urban migration and government policies in low income countries, International Labour Review, 118, pp. 747-762.

Post Courier (1994) Settlers flee from Rabaul into West New Britain, 8 February.

Post Courier (1997a) Settlers blame police for Madang blazes, 25 July.

Post Courier (1997b) Police warn settlers to cooperate, 28 July.

Post Courier (1997c) Squatters get three months notice to move off State-owned land, 31 July.

Post Courier (1997d) Madang settlers announce plans to fight evictions, 7 August.

Post Courier (1997e) Kas: Yes to evictions, 26 August.

Post Courier (1997f) Business urges vagrancy laws and ID cards, 3 September.

Post Courier (1997g) Displaced settlers crowd around police station, 23 October.

Post Courier (1997h) 'Fighting Zone' edict for Madang, 19 December.

Post Courier (1998a) Madang settlers spared eviction, 8 January.
Post Courier (1998b) Chief Justice says eviction may breach people's rights, 12 January.

Post Courier (1998c) Influx of immigrants into blocks worry, say Poro settlers, 3 February.

Post Courier (1998d) Evictions aimed at stopping spread of illegal squats, 4 February.

Post Courier (1998e) Bring back Vagrancy Act, 13 February.

Post Courier (1998f) Government stops debate on urban drift, 9 July.

Post Courier (1998g) Madang settlers bulldozed out, 8 January.

Post Courier (1998h) Kidu helps settlers to head home, 30 November.

Post Courier (1999a) Settlers swept out in Kokopo, 2 March.

Post Courier (1999b) "I have no choice but to evict", 3 March.

Post Courier (1999c) Excessive force 'not legal', 4 March.

Post Courier (1999d) Diro does deal on squatters: villagers vow to aid evictions, 18 March.

Post Courier (1999e) Squatter influx, 20 May.

Post Courier (2000a) Policy needed on squatters: Genia, 16 August.

Post Courier (2000b) City ban on new urban squatters, 23 October.

Post Courier (2000c) Central: get rid of all camps, 1 November.

Post Courier (2000d) Madang suffering silently, 6 November.

Rawlings, G. E. (1999) Foundations of urbanisation: Port Vila town and Pango village, Vanuatu, Oceania, 70, pp. 72-86.

RidDELL, J.B. (1978) The migration to the cities of West Africa: some policy considerations, Journal of Modern African Studies, 16, pp. 241-260.

Ryan, D. (1966) Toaripi-speaking people in Port Moresby. Unpublished seminar paper, Australian National University, Canberra.

RyAn, D. (1989) Home ties in town: Toaripi in Port Moresby, Canberra Anthropology, 12, pp. 19-27.

RYAN, D. (1993) Migration, urbansiation and rural-urban links: Toaripi in Port Moresby, in: V. S. Lockwood, T. G. Harding and B. J. Wallace (Eds) Contemporary Pacific Societies: Studies in Development and Change, pp. 219-232. Englewood Cliffs, NJ: Prentice Hall.

SchePer-Hughes, N. (1992) Death without Weeping: The Violence of Everyday Life in Brazil. Berkeley, CA: University of California Press.

SikANI, R. (2000) The criminal threat in Papua New Guinea, in: B. BoeHa and J. McFarlane (Eds) Australia and Papua New Guinea: Crime and the Bilateral Relationship, pp. 35-56. Canberra: Australian Defence Force Academy. 
Simmons, A. (1979) Slowing metropolitan city growth in Asia: policies, programmes and results, Population and Development Review, 5, pp. 87-104.

Somare, M. (1973) New goals for New Guinea, Pacific Perspectives, 2, pp. 1-4.

Talyaga, K. K. and Olela, C. (1978) The Debate on Repatriation of Squatters and Vagrants from the North Solomons Province (1977-78). Port Moresby: IASER.

Townsend, D. (1977) Finding the Road: The Factors of Distance and Transport in Socioeconomic Development in the Huon Peninsula of Papua New Guinea. Melbourne: Monash University.

WARD, M. (1970) Urbanisation-threat or promise?, New Guinea, 5(1), pp. 57-62.

WARD, R. G. (1971) Internal migration and urbanisation in Papua New Guinea, New Guinea Research Bulletin, 42, pp. 81-107.
WARD, R. G. (1980) Migration, myth and magic in Papua New Guinea, Australian Geographical Studies, 18, pp. 119-134.

Ward, R. G. (1997) Pacific Islands urbanisation: trends, issues and questions. Keynote paper in the Population Session Pacific Science Intercongress, Suva, Fiji.

WARD, R. G. (1998) Urban research in the Pacific Islands: a brief review, Development Bulletin, 45, pp. 22-26.

Young, E. A. (1977) Simbu and New Ireland migration. Unpublished $\mathrm{PhD}$ thesis, Australian National University, Canberra.

Zimmerman, L. (1973) Migration and urbanization amongst the Buang of Papua New Guinea. Unpublished $\mathrm{PhD}$ thesis, Wayne State University, Detroit. 